\title{
Handle with care
}

Scientists are rushing to defend a colleague charged with mishandling samples of the plague bacterium. But they must be careful not to send the message that microbiologists are blasé about the need to protect public health.

W hen Thomas Butler stepped off a plane in April 2002 on his return to the United States from a trip to Tanzania, he set in motion a chain of events that now threatens to destroy his life. A microbiologist at Texas Tech University in Lubbock, Butler was bringing back samples of the plague bacterium Yersinia pestis for his research. Yet on re-entering the country, he is alleged to have passed right by US customs inspectors without notifying them that he was carrying this potentially deadly cargo.

That move and its repercussions have led the federal government to prosecute Butler for a range of offences. He was arrested in January after declaring to federal officials that plague samples had gone missing. Butler then admitted — under duress, he now claims - that he had destroyed the samples without following federal guidelines for handling such dangerous materials. His trial began in Lubbock on 3 November. If convicted on all counts, he could be fined millions of dollars and spend the rest of his life in jail.

The US scientific community has leapt to Butler's defence, arguing that his prosecution is overzealous, alarming and unnecessary. The presidents of the National Academy of Sciences and the Institute of Medicine have written to Attorney General John Ashcroft, claiming that the case could endanger research into countering the threat of bioterrorism. And the academy's human-rights committee has asked its members to write letters on Butler's behalf and to donate funds for his defence (see Nature 425, 5;2003).

Those who defend Butler argue that the rules governing the import of pathogens are so restrictive that bending them is the only option for researchers who are working to provide protection from deadly diseases that afflict the developing world (see Nature 423, 669; 2003). Why, they ask, prosecute Butler for infractions of rules that made his work more difficult without serving a useful purpose?
The charges laid against Butler run further than his alleged flouting of import controls, however. He is accused of having travelled across the United States with plague bacteria at least twice last year, and of shipping plague samples back to Tanzania with a label identifying the contents merely as 'lab materials'. He is also charged with inflating research expenses to avoid $\$ 40,000$ in taxes.

His supporters counter that this damning charge sheet merely reflects the determination of federal prosecutors to throw the book at Butler to make an example of him to others. Many researchers now fear falling victim to an overzealous prosecution if they fail to dot all the 'i's and cross all the 't's on their paperwork. Some US microbiologists are so frightened of being hauled off in handcuffs for a minor administrative oversight that they have decided to avoid biodefence research entirely - despite the current funding bonanza in the field.

Whether Butler is a villain or a scapegoat is now for a jury to decide. But whatever verdict is eventually reached, scientists who are lobbying on Butler's behalf would do well to consider public perceptions. If the rules governing the import of pathogenic bacteria make no sense, then microbiologists must make that case clearly, and lobby for the regulations to be changed. Researchers are also justified in making representations to help ensure that any punishment that Butler might receive is proportionate.

But researchers risk a damaging public backlash if the main message that emerges is that his peers think he was justified in carrying samples of the plague bacterium onto a commercial flight. Appearing to deny the importance of rules designed to protect the public from deadly pathogens - however unwieldy those rules may be in practice - will not engender trust. It will not foster a culture of responsibility. And it would show disregard for the public's faith that scientific research will be conducted as safely and as competently as possible.

\section{Defamation, online}

\section{Operators of preprint archives and other scientific websites would be well advised to get up to speed on media law.}

$\mathrm{R}$ egular users of the ArXiv physics preprint server know that its contents occasionally depart from the dry format of the standard scientific manuscript - recent examples include an essay that draws parallels between astrophysics and prostitution (M. López-Corredoira, preprint at http://arxiv.org/astro-ph/0310368; 2003). For the most part, such contributions serve as mild irritations or amusing distractions, depending on your point of view.

But a posting made on 27 October (A. De Rújula, preprint at http://arxiv.org/physics/0310134; 2003) raises more serious concerns. The preprint accuses Britain's astronomer royal of claiming credit for other researchers' ideas. And legal experts contacted by Nature argue that the language used could, under some jurisdictions, be considered libellous (see page 7).

Magazines, newspapers and some scientific journals consult specialists in media law before publishing articles that are potentially defamatory. They also take out insurance to cover the eventuality of losing a libel suit. But the operators of preprint archives have not, until now, seen the need to take such precautions. Paul Ginsparg of Cornell University, who runs ArXiv, argues that a preprint server cannot be judged by the standards of a newspaper.

In some respects, he is correct - under many jurisdictions, the operators of a website won't necessarily be assumed to have read and approved every posting made. But in the event of a complaint being made, things get complicated. The Internet's international reach means that a website's operators can, in theory, be held liable under the law of any country in which the material is accessed. In the case of a potentially libellous posting, that could mean weighing the probable liability under England's tough defamation laws, if the posting were not removed, with a US author's right to free speech, enshrined under the First Amendment to the constitution.

Thankfully, most scientists are not especially litigious. But losing just one legal action can cost an awful lot of money. If De Rújula’s posting marks the start of a trend, every operator of a preprint server may need to find a good lawyer. 